\title{
MIRLET7F1 Gene
}

National Cancer Institute

\section{Source}

National Cancer Institute. MIRLET 7F1 Gene. NCI Thesaurus. Code C80705.

This gene is involved in the regulation of gene expression and plays a tumor suppressor role in lung carcinoma. 